\title{
AN INTRODUCTION TO VARIOUS ISSUES SURROUNDING THE OWNERSHIP OF STORAGE/PIPELINE GAS
}

\author{
CHRIS SIMARD* AND ANDREW LAMB**
}

The issues surrounding ommership of pipeline and stored gas have been langely ighored in Canada, with the result that momy in the industry mon be surprised to learn that their inferests in such resources are not necessarily secured. By applying the most recent legal decisions in Canada and the U.S. to the practical possibility of an operator's insolvency. the authors discuss the likelihood, explore the advantages, and address the dangers of casting this relationship as a tenancy in common. hailment. or must. While the importance of protecting a client's rights through extensive comeracual principles is paramoun in every relationship, the exfen to which the judiciary will

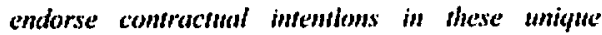
circumstances is for from certain. This article explores the practical questions respecting issues of ownership and securing as regards the natural gas arena to propose finally a new class of ownership that would treat natural gas rights as a sui generis categony unique to storage/pipeline gas.
Les questions relatives à la propriéte de gazoducs et gaz entrepoxi som an grande partic ignories an Canok et par conséquent beaucoup d'acteurs dams

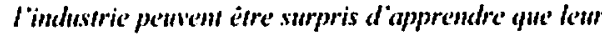
participation dans ces ressources n'est pas necessairement protégée. En exécutam les dernieres decisions judicaires du Canada et des États-Unis relarivement à la possibilité pratique qu un exploikm deviome insolvable. les auteurs discutem de cette probabilite. cxplorem les avantages et abordent les dangers de diffuser cette relation comme etams whe benonce commune. un baillement ou une fiducie. Bien qu' il soil primordial de prokger les droits du cliem an moyende principes contractuch tres vasues dans foutes les relations, fa mesnere doms laquelle la magistrame accoptera les intentions contractwelles dans ces cinconstances speciales est loin d'etre cerfaine. (a) article examine les questions pratiques relatives anx problimes de propriété et sécurité en ce qui concerme le domainc du gaz naturel afin d'arriver finalemenl à une nowelle culegorie de propriete de gaz entreposi et gazoducs où les droits du gaz naturel scroicm traife's comme une categorie unique sui generis.

\section{TABLE OF CONTENTS}

I. INTRODUCTION ............................... 514

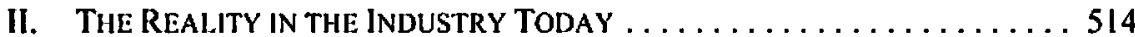

III. THE CURRENT LAW REgaRDING OWNERSIIP OF STORFD

and Transported Gas $\mathbb{N}$ Western Canada ............. 515

A. The Trutil About Commingling; ................ 515

B. ThF. "DEFAULT" POSITION

- Trenancy in Common ........................ 515

C. INTENTION OF THE PARTIES AND

Contractual ARRANGEMENTS ................. 518

D. Tile Efficacy of Purporting to Rftain Title:

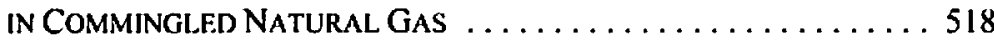

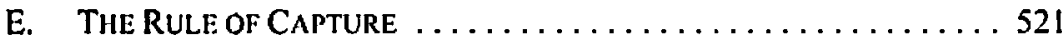

IV. THE INTERACTION OF AN OPERATOR'S BANKRUPTCY OR

INSOLVENCY AND NATURAL GAS OWNERSHIP ............ 523

A. INTRODUCTION TO BANKRUPTCY AND
INSOLVENCY PRINCIPLLS $\ldots \ldots \ldots \ldots \ldots \ldots \ldots \ldots \ldots \ldots \ldots \ldots \ldots \ldots \ldots \ldots$
523

B. OplekATOR BANKRUPTCY SCENARIOS $\ldots \ldots \ldots \ldots \ldots \ldots \ldots 525$

- Partner, Bankruptcy and Restructuring Group, Bennell Jones LLP, Calgary, Alberta.

*- Associate, Energy and Natural Resources Group, Bennett Jones LLP, Calgary. Alberna. 


\section{THE DIFHICULTY WITH ASSERTING OWNERSHIP RigIITS

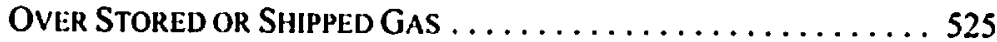 \\ D. Personal Property Security Considerations ......... 530 \\ V. Moving TowardS a New Category of OWNERSHIP .......... 536}

\section{INTRODUCTION}

The goal of this article is to highlight various legal and practical issues respecting the ownership of stored and transported natural gas' in Western Canada. The law in this area is less well developed in Canada than it is in the United States. The common law and the statutory regimes that likely apply in Western Canada may produce results that will be of surprise to the industry. It is hoped that by identifying the legal issues, readers will gain an appreciation of the important ramifications of the question of ownership, and be better able to structure their or their clients' contracts.

Our approach will be first to discuss the law that is likely applicable to the issue of ownership of stored and transported natural gas in Western Canada, and to contrast our regime with that of the United States. We will then discuss the practical consequences of the applicable legal regime in the context of a potential bankruptcy or insolvency of a storage or pipeline operator (given that this is the context in which ownership issues become most crucial). Finally, we will consider the manner in which the law in this area might develop, and the likelihood that Canadian courts will adopt the U.S. approach.

\section{The Reality in THE INdUSTRY TODAY}

Despite its integration, the natural gas transportation industry in Western Canada has not developed a uniform system of ownership over natural gas as it travels from the wellhead through gathering systems and midstream processing facilities and into storage or transportation pipelines for delivery to the consumer. The result has been a variety of different contractual treatments, with no uniform approach. Some contracts grant title (along with risk and possession) to the operator, some state that the producer retains title but risk and possession pass to the operator, and some are completely silent as to ownership and only deal with risk and possession.

Probably because the industry runs so well, and probably also because, at least with respect to pipeline gas, the length of time involved is so abbreviated, ${ }^{3}$ the issue of ownership over pipeline gas and stored gas (both in tanks and subsurface reservoirs) has been largely ignored. The same is true of other issues ancillary to the ownership question, such as security interests in stored or shipped gas, and the priority of such security interests in the event of an operator's or producer's insolvency.

In this article, the lerms "natural gas" and "gas" both refer lo natural gas.

In this article, the $\mathrm{term}$ "operator" refers to an operator of either a natural gas storage facility or a natural gas transportation pipeline, unless otherwise indicaled.

In fact, with respect to the large midstream pipelines that operate on an inventory system (e.g., Nova Pipeline's NIT system), the period of time that ownership over injected gas is an issue is one day. 
While the likelihood of a pipeline or storage facility operator becoming insolvent may be remote, it is always a possibility. It is extremcly useful to consider the issues that would arise in such an insolvency, because insolvency provides a useful perspective from which to assess critically the issue of ownership of stored and shipped gas. As well as an operator's insolvency, the ownership issue will arise in other scenarios, such as an operator's (or producer's) lender's due diligence and assessment of an operator's or producer's credit risk, and ways of reducing such risk.

\section{The CuRrent Law Regakding OWNERShIP OF StORFD AND TRansported Gas in Western CaNada}

\section{A. The. Truth About Comminglang}

The basic intractable fact in all storage or transportation situations involving gas from more than one producer is commingling. Once a producer delivers its gas to the operator, it never expects to (nor can it) get back, or have delivered to its customers, the exact molecules of gas that it put into the system. The same is true of all fungible goods that become mixed. Instead, various measuring, balancing, and accounting processes take place, with the goal of returning to the producer (or crediting to the producer's account with the operator) a quantity of gas or, more often, heat energy, equivalent to that delivered by the producer. Natural gas marketers have the same expectation. ${ }^{\dagger}$ As will be discussed below, the commingled nature of shipped and stored gas is the single most important consideration in approaching the ownership issue.

\section{B. The: "Defaul.t" Position - Thenancy in Common}

Despite the fact that no Canadian cour has decided the question in the context of stored or shipped natural gas, it is likely that the law, absent contractual agreements to the contrary, will treat producers as tenants in commons in respect to stored or shipped gas. The operator is probably also a tenant in common, based on its initial ownership of line fill (in the transportation context) or base gas ${ }^{6}$ (in the storage context).

\section{Common Law Regarding Tenancy in COMmon}

\section{Halshury's Laws of England states:}

Where chattels of two persons are intermixed by agreement. so that the several portions can no longer be distinguished, the proprietors have an interest in common in proportion to their respective shares.

+ In this article, the term "producer" reters to the producers of natural gas and similarly situated owners of natural gas, such as gas marketers.

Tenancy in common is also referred to in law as co-ownership or uwnership in common. Sec E.L.G. Tyler \& N.E. Palmer, eds. Crossley Vaines on l'ersomal Propert!̣. Sth ed. (l,ondon: Bulterworths, 1973) al 56.

- Base gas, also known as native gas, is natural gas that was never produced from a gas storage reservoir during its gas production phase (i.e., prior to the rescrvoir being used as a gas storage reservoir).

Halshur' 's Low's of Englond, th ed., vol. 2 (London: Butterworths, 1991) at para. 1836 [footnotes omilted]. See also R.M. Goode, Proprietary Rights and Insolvency in Sales Transactions, 2d ed. (London: Sweet \& Maxwell, 1989) at 6: "Ownership in common typically arises where products 


\title{
The American position is substantially identical:
}

\begin{abstract}
Where the intermixture occurs with the consent of the owners of all the parcels mixed, whether such goods be of a character to be separable by a proportional division or not, it is obvious that all the owners involved have equal equitics in the situation they have created and become what is technically known as tenants in common, with all rights and obligations incidental to that relation. This is the relationship that arises when owners of parcels of grain deposit them together in a common wareloouse. Each depositor loses his title to the specific grain which he has deposited and becomes with the depositors an owner in common of the entire mass in the proportion which the amount he deposited bears to that mass. ${ }^{*}$
\end{abstract}

Given the nature of the natural gas transportation industry, producers who deliver their gas for storage or shipment have very likely consented, at least implicitly, to the commingling of their gas with that of other producers and of the operator.

In Canada, the concept that contributors to an intermixed mass are tenants in common was first recognized in the context of intermixed logs. ${ }^{y}$ This position is also supported in the context of tires. ${ }^{10}$

The law in this area in the context of hydrocarbons was canvassed in Indian Oil Corp. v. Greenstone Shipping SA." In that case, the defendant combined its own oil with oil of approximately equal grade belonging to the plaintiff in the cargo hold of the defendant's vessel without the plaintiff's consent. Justice Staughton reviewed the authorities in detail and held that the plaintiff was a tenant in common with the defendant, and was therefore only entitled to receive out of the commingled mass a volume of oil equal to the entire amount of oil it had had delivered to the vessel. The plaintiff had no claim to the portion of the commingled mass in excess of that amount that resulted from the defendant's wrongful commingling of the plaintiff's oil with that of the defendant.

\section{WAREHOUSE RECEIPTS ACT}

The Warehouse Receipts Act ${ }^{12}$ was first enacted in the 1940 s and is a little-known piece of legislation in the natural gas industry. Many industry participants will be surprised to learn of its likely applicability to natural gas storage situations.

belonging to different owners become commingled, as in the case of gas or oil brought ashore in a pipeline."

" Ray Andrews Brown. The Law of Personal Propern!, 3d ed. by Walter B. Raushenbush (Chicago: Callaghan \& Co.. 1975) at 64.65 [footnotes omitled].

McDonald v. Lane (1882), 7 S.C.R. 462.

10 Firestone Tire \& Rubber Co. of Camada L.dd. v. North Star Oil I.td. (1960), 25 D.L.R. (2d) 139 (Man. Co. Cl.).

1 [1987] 3 All E.R. 893 (Q.B.D.).

: R.S.A. 2000, c. W-1 [WRA]. 
Section 15 of the WRA states:

When authorized by agreement or by custom, a warehouser may mingle fungible goods with other goods of the same kind and grade, and in that case the holder of the receipts for the mingled goods owns the entire mass in common, and each holder is entitled to such proportion of it as the quantity shown by the holder's receipt 10 have becn deposited bears to the wholc. ${ }^{13}$

As the WRA was first proclaimed in the 1940s, it is doubtful that natural gas storage operations were the situations to which the WRA was originally meant to apply. Nonetheless, there is nothing in the $W R A$ suggesting it would not be found to apply to gas storage operations:

1) Storage operators fit within the WRA's definition of a "warehouser," 14 and operators are allowed to commingle the delivered gas, if not explicitly by agreement, then definitely by custom. It is likely, however, that natural gas pipelinc operators are not captured by the definition (as natural gas is delivered to pipelines for Iransportation, not storage) and, therefore, the $W R A$ probably does not apply to Iransportation agreements;

2) Although base gas, if any is present in a storage cavern, may not be considered fungible for the purposes of $\mathrm{s}$. 15 of the $W R A$ because it has not been processed to remove sulphur, water, other hydrocarbons, etc., all delivered gas likely would be considered fungible; and

3) If base gas was present, there would be practical problems in calculating what proportion of the commingled mass each producer would be entitled to, as the total amount of gas present would not be known. However, this would only be an issue if there was less gas in the reservoir than the total amount of gas that had been delivered by the producers. Further, if the base gas was actually fungible (thereby removing the potential problem identified above), each producer would acquire an interest in the base gas, as well as in all delivered gas. Therefore, it would only be in situations where the volumetric sum of all the delivered gas and the base gas was less than the total volume of gas that the operator was contractually obliged to return to the producers that the calculation implied in s. 15 of the WRA would be required.

None of the foregoing points would seem to displace the applicability of the WRA. The most problematic factor in determining its applicability would be whether producers, pursuant to storage agreements, are in possession of anything that qualifies as a "warehouse receipt" for the purposes of the $W R A$. The $W R A$ defines a warehouse receipt as "an acknowledgment in writing by a warehouser of the receipt for storage of goods not the Recejpts Acts: see R.S.B.C. 1996, c. 481, s. 14; R.S.Y. 2002, c. 227, s. 14; C.C.S.M., c. W-30, s. 15; and R.S.O. 1990, c. W.3, s. 14, respectively: Saskatelıewan and the Northwest Territories do not have an equivalent provision in their legislation.

14 The WRA defines a "warchouser" as "a person who receives goods for storage for reward" (supra note 12, s. I(k) [emphasis added]). 
warehouser's own." "It is possible that written nominations of natural gas to be delivered for storage, possibly in conjunction with an operator's own records of measurements, would satisfy the WRA's requirement for a warehouse receipt.

With the common law hierarchy ascending from common law to legislation to, in most situations, private contracts, the common law and $s .15$ of the WRA support the conclusion that, in Canada, subject to anything to the contrary in the gas storage contract, ${ }^{16}$ all producers would likely be found by an Alberta court to have a tenancy in common interest in the entire mass of stored natural gas.

\section{Intention of the Parties and Contractual ARrangements}

We will now consider the manner in which industry players are currently dealing with ownership issues in storage and transportation contracts, and how such arrangements interact with both the common law and the WRA.

Parties to transportation and storage agreements have typically attempted to arrange their affairs with respect to ownership over the gas in one of two ways. The more common arrangement is for the producer to retain title to the delivered gas while possession (and usually risk) transfers to the operator. Although the actual word is not often seen in these types of agreements, this is an attempt by the parties to create a bailment in respect to the delivered gas. Under a bailment, a bailor (e.g., the producer) retains title in goods while a bailee (e.g., the operator) takes possession of the goods for a limited purpose (such as transportation or processing) and for a limited time. The other, less common, arrangement is for the operator to acquire title to the gas for the period of time that the gas is in its possession. As will be discussed below, if the gas streams that flow through the operator's pipeline or storage facility are not all dealt with in the same manner in respect to ownership (i.e., some, but not all, producers have purported to retain title), those producers who have not retained title might be prejudiced in the event of an operator's insolvency.

\section{The Efficacy of Purporting to Retain Title in COMMINGLED NATURAL GAS}

Given the factual reality of pipeline and storage commingling and the impossibility of a producer getting back the very gas molecules it has delivered to the operator, is it possible in law for a producer to retain title in its shipped or stored gas? Put another way, does commingling of fungible property obviate any attempt to create a bailment of such property?

One answer might be that two parties can create whatever relationship they desire, including a bailment, regardless of the factual context of the transaction. However, the following quote from Re Speedrack Lid. ${ }^{17}$ is instructive in this regard: 
The nature of the transaction may be apparent on the face of the instruments, but if it is not, the cour must determine its nature ... from the surrounding circumstances. It is not merely a question of construing the agreement between the parties, which may be quite clear. It is a question of delermining the intention of the partics, notwithstanding the form used in setting up the transaction. For this, extrinsic evidence may be relevant and admissible. ${ }^{18}$

Although a determination of the nature of the transaction in Speedrack was required for the purpose of determining priority of security interests in personal property, the same principle (i.e., substance over form) also applies to determining whether a transaction is a bailment or something else. ${ }^{19}$ The title retention clause in a storage or transportation agreement will not be interpreted in isolation, and when the entire wording of the agreement is reviewed in the factual context of commingling, the title retention wording may be held not to govern.

To determine how a court would treat this issue, it is necessary to consider first the nature of bailment in greater detail.

Bailment is a category of ownership created by common law. N.E. Palmer's text, Bailment, ${ }^{20}$ states that the essence of bailment is that the bailed property should be returned to the bailor when the bailment terminates. While the goods need not be in their precise original form, "[w]hat is necessary is that the goods themselves, whether in altered or original form, should be returnable and not merely some other goods of equivalent character or value."21 In South Australian Insurance, the Privy Council held that a consignment of grain that was immediately commingled with other grain in an elevator did not create a bailment but a sale of the grain, possibly subject to the original owner's right to repurchase an equivalent quantity at a future time.

While there is no Canadian case law dealing with this question specifically in the context of petroleum or natural gas, there are reported decisions involving cattle and precious metals that draw the same conclusion. In Crawford v. Kingston,"2 which involved cattle, the Court cited South Australian Insurance and stated:

\footnotetext{
Whenever there is a delivery of property on a contract for an equivalent in money or some other valuable commodity, and not for the retum of the identical subject-matler in its original or an allered form, this was a transfer of property for value ... and not a bailment... [t]f ... the contract ... deces not repuire the party receiving the chattel to relum it in its original or an altered form ... the relation of vemlor and purchaser is created and the title to the property passes to him and is in him. ${ }^{23}$
}

Ibid. at 213.

South Australian Insurance Co. v. Randall (1869), L.R. 3 P.C. 101 [Somb Austratian Inxurance]. N.E. Palmer, Builment, 2d ed. (Sydney: Law Book, |99|).

Ibid. at 135. See also Bruce H. Ziff. Principles of Properiy /.aw, 4th ed. (Toronto: Thomson Carswell, 2006) and Derek Mendes Da Costa \& Richard J. Balfour, Property Law: Cases, Text amed Malerials, 2d ed. by Eileen E. Gillese (Turonto: Emond Montgomery, 1990).

[1952] O.R. 714 (C.A.) [Crusford].

lbid. at 717 . 
In Re Della Smelting \& Refining Co., ${ }^{2+}$ McLachlin C.J.S.C. (as she then was) held that none of the bankrupt refinery's customers, each of whom had delivered gold or silver to the refinery on the condition that it be relurned after refining, had a proprietary interest in the proceeds from the sale of those metals. The reason was that the metals were intentionally commingled with the customers' consent, making it impossible for them to be the subject of a bailment.

Therefore, Canadian courts have consistently upheld the principle that if the identical personal property delivered by an owner cannot be returned to the owner, a bailment is impossible. There is nothing in these cases that indicate a similar result would not be arrived at in the context of hydrocarbons.

However, there is U.S. authority specifically in the context of natural gas that strongly supports the proposition that commingling of natural gas does not negate the ability to create a bailment. ${ }^{25}$ In Public Service Electric \& Gas Co. v. Federal Power Commission, ${ }^{26}$ the Federal Court of Appeal, Third Circuit, rejected the argument that commingled gas being transported on a pipeline from Texas to New Jersey could not be the subject of a bailment. The Court stated: "An essential ingredient of an exchange [i.e., a sale] is a transfer of title, and this was clearly not intended by the parties. The arrangement between [the producer and the operator] would involve nothing more than the bailment of a fungible commodity."27

Public Service was followed in Bristol Industries..$^{28}$ In that case, the plaintiff contracted to ship scrap metal to the defendant for conversion into alloy strips, which the plaintiff would repurchase. The defendant commingled the metal received from the plaintiff with metal from other customers. When the defendant became bankrupt, the plaintiff brought an action seeking possession of and title to the metal it had shipped to the defendant, arguing that the arrangement was a bailment. On appeal, the trial decision to dismiss the action was overturned. Justice Mansfield stated that the trial judge had erred in finding that a bailment could not exist as the metal had been commingled:

Second, the trial judge erred in holding that the law of bailments is inapplicable to fungible goods. When commingling is required by the needs of the trade and is done with the consent of the parties a bailment is established if that is the intenl of the parties. ${ }^{29}$

In Canada, no court has yet endorsed the proposition that an agreement to create a bailment of fungible goods will govern, despite commingling and the impossibility of returning the bailor's chattels to it. A court called on to decide the matter in the future would be faced on the one hand with American and English jurisprudence and a clear contractual

(1988). 33 B.C.L.R. (2d) 383 (S.C.) [De/ha].

" There is also English authority in the comlext of grain that supports this proposition. Sec Mercer $v$. Croven Grain Storage I.sd., $\mid 1994]$ C.I.C. 328 (H.L.), and its treatment in Lionel D. Smith, "Bailment Witl Authority to Mix - and Substitule" (1995) III Law Q. Rev. 10.

-6 371 F.2d I (3d Cir. 1967) [Public Service].

:7 Shid. at para. 9. See also Brown. supra note 8 and $8 A$ Am. Jr. 2d, Bailments $\$ 40$.

:* In re Bristol Industries Corp., 690 \$.2d 26 (2d Cir. 1982) [Bristol Indhstries]. See also In re Fuel Oil Supply d Terminaling Inc.. 837 F.2d 224 (5th Cir. 1988).

* Bristol Industries, ibid. al 30. 
intention (presuming a well-drafted title retention clause) to create a bailment, and on the other hand with a well-entrenched Canadian common law principle and warehousing legislation obviously not drafted with natural gas transmission and storage in mind.

One might think that the parties' stated intention would govern, but courts have not always found that title to fungible goods stays with the customer in a transportation or storage agreement, even when the agreement clearly states that it does. ${ }^{30}$ With no Canadian jurisprudence to bind it or guide it, a court in a bankruptcy or insolvency proceeding could certainly be persuaded by a bank's or other creditor's counsel to rely on:

- the Crawford and Della cases, which, although involving grain and precious metals, could be argued to be analogous to the natural gas industry; or

- the Canadian common law principle and, in the case of gas storage operations in provinces with an equivalent to the $W R A,,^{31}$ legislation that state contributors of fungible goods to a commingled mass own the mass as tenants in common

and find that the delivered gas, once commingled, was no longer owned in full by any party and that instead: (a) title to the gas had been transferred to the operator; or (b) the entire commingled mass of natural gas was owned as tenants in common by all parties that had contributed to it. Such a finding would be especially possible where the transportation or storage agreement was silent on the issue of title to delivered gas. If the parties' contract does not contain a well-drafted title retention clause, the possibility of persuading a court that the arrangement is a bailment will be lessened.

Until there is Canadian jurisprudence on the topic, the only thing producers can do is to try to negotiate transportation or storage agreements so as to evidence a clear and unequivocal intention that title to the delivered gas remains with them, notwithstanding any commingling or (in the storage context) legislation. Indeed. some title retention clauses in use in transportation and storage agreements in Western Canada exceed one page in length in an effort to do just that.

\section{E. Tie Rule of Capture}

Before moving on to discuss the importance of the ownership issues highlighted thus far in the bankruptcy and insolvency context, the applicability of "the rule of capture" to stored gas will be briefly analyzed.

The rule of capture is premised on particular assumptions about the ownership of certain classes of things that are migratory in nature. ${ }^{32}$ The rule has been expressly adopted in the context of petroleum and natural gas in Canadian jurisprudence. The Supreme Court of Canada recognized that the "proprictary [i.e., ownership] interest [in oil or gas] becomes real

Sec, e.g. Cangill l.te. s. Hoeppner (1996), 109 Man. R. (2d) 81 at para. 13 (Q.B.), in the context of cattic.

Supra note 12.

32 In the nineteenth century, the relevant cases oflen involved wild animals. In the twentieth century, the subject matter was often hydrocarbons. 
only when the substance is under control, when it has been piped, brought to the surface and stored." 33

The application of the rule of capture to stored gas (i.e., gas that has been previously produced and re-injected underground for storage) has not arisen in Canada, but guidance can be obtained from American jurisprudence. Some early U.S. cases relied on legal theories of ownership to hold that once gas was injected for storage, ownership could no longer be determined and the injected gas was subject to capture. ${ }^{34}$ This approach, however, was overruled in later decisions, and presently the consensus U.S. position seems to be that where the person injecting the gas did not intend to abandon it, and has injected it into an adequately defined cavern, the ownership of the gas remains with that person. ${ }^{35}$ Abandonment is only to be inferred where oil or gas has been injected into "a formation that is not well defined, [thus] the owner has physically relinquished the property by putting it beyond control ... [Abandonment will not be inferred where] the injector reasonably believes that the storage reservoir is well defined." ${ }^{36}$

If the injector does not have either the contractual or the statutory right to re-inject the gas. there will be a risk that re-injected gas may again become subject to the law of capture. ${ }^{37}$ However, pursuant to the statutory scheme in place in Alberta, it can be argued that such reinjection rights are granted to all holders of petroleum and natural gas rights, at least implicitly. Sections 57(1) to (4) of the Mines and Minerals $\mathrm{Act}^{38}$ state:

(1) Subject to subsection (2).

(a) where a person owns the title to petroleum and natural gas in any land, that person is the owner of the storage rights with respect to every underground formation within that land...

(2) Where a person owns title to a mineral in any land and operations for the recovery of the mineral result or have resulted in the creation of a subsurface cavern in that land, that person is the owner of the storage rights with respect to that subsurface cavern to the extent that it lies within that land.

A person who has storage rights in respect of a subsurface cavern within any land has the right to recover any fluid mincral substance stored in that cavern, to the exclusion of any other person having the right to recover a mineral from the same land.

In subsections (1) to (3), "person" includes the Crown in right of Alberta.

Berkheiser v. Berkheiser, [1957] S.C.R. 387 al 391 [Berkheiser]. See also Boris v. Camadian Pacific Raihwa, [1953] 2 D.L.R. 65 (P.C.).

Sec, e.g. Ilammonds v. Cintral Kentucky Nutural Gas Co., 75 S.W.2d 204 (Ky. App. Ct. 1934).

Ste, c.g., Leme Stow Gas Co. v. Murchison, 353 S.W.2d 870 (Tx. Ct. Civ. App. 1962).

F. Kuntz, Kimtz Oil and Gow - A Revision of Thormen (Cincinnati: Anderson Publishing Co.. 1987) at 71.

But see Bennett Jones Verehere \& Nigel Bankes, Canadian Oil and Gas, 2d ed., vol. I. looseleaf (Markham, Ont.: Butlenwonths Canada. 1993) at 2.14. See also Anderson v. Beech Aircraft Corp., 699 P.2d 1023 (Kan. 1985).

R.S.A. 2000, c. M-17 [M/M.A]. 
From this, assuming that storage operators have title to the petroleum and natural gas reservoirs into which the natural gas is being re-injected or stored, storage operators likely have the sole (statutory) right to inject and recover the delivered natural gas. As there is no explicit intention to abandon the injected natural gas, the rule of capture will likely not be held to apply, so long as the reservoir is, or is thought to be, well enough defined such that the operator could retain physical control over the injected natural gas.

It should be noted that $\mathrm{s} .57(3)$ does not grant the storage operator title to the natural gas stored in a cavern; it simply gives the operator the right to recover it. Title, and therefore ownership, over the stored gas is not decided by the $M M A$.

Having introduced the general issues surrounding the ownership of stored and shipped natural gas, it is appropriate to move to a discussion of bankruptcy and insolvency law, to gain an appreciation of when the ownership issues will "matter" and why.

\section{THE INTERACTION OF AN OPERATOR'S BANKRUPTCY OR INSOI.VENCY AND NATURAL GAS OWNERSHIP}

\section{A. Introduction to BANKRUPTCY AND InsolvenCy PRINCIPLES}

This article is not intended to be a treatise on bankruptcy and insolvency law. Rather, we will only briefly identify those principles of bankruptcy and insolvency law that will impact the rights of a producer.

There are three fundamental principles of insolvency law that are important in this context. These three principles apply, with only slight modifications, in all the different types of formal Canadian insolvency proceedings (i.e., receiverships, interim receiverships, bankruptcies, Companies ' Creditors Arrangement $A c t^{39}$ proceedings, and proposals under the Bankruptcy and Insolvency $A c r^{+0}$ ). The three fundamental principles are:

- Preservation of Pre-Insolvency Entitlements: a creditor's rights in a debtor's insolvency are determined by the pre-existing rights that the creditor enjoyed as at the commencement of the debtor's insolvency;

- Recourse to Debtor's Assets Only: once the insolvency proceeding commences (subject only to a few exceptions), the debtor company or insolvency representative (and the debtor's creditors) have recourse only to the property that was owned by the debtor at the time of the insolvency (i.e., only the debtor's own assets are available for distribution to its creditors); and

- Paymemt in Accordance with Pre-existing Priority: secured creditors' respective entitlements to the debtor's assets are determined by a priority system, whereby first priority creditors are paid in full before lower-level priority creditors receive 
anything. Generally speaking, the priority that existed at the commencement of the insolvency does not alter thereafter.

Given these three fundamental concepts, it is easy to see that certain queries must necessarily be answered in virtually every insolvency proceeding:

- What assets were owned by the debtor at the commencement of the insolvency and, therefore, were available for distribution to creditors (or stated another way, was a particular asset owned by someone other than the debtor at the start of the insolvency and, therefore, unavailable to the debtor's creditors)?

- With respect to the assets that were owned by the debtor at the start of the insolvency, what rights (i.e., security) did creditors have in those assets at that time?

- What is the relative priority of such creditors' rights in those assets?

The issue of ownership of assets at the date of the insolvency is determined by the common law, equity, and statutes, rather than by specific rules of insolvency law. Natural gas, once captured and extracted, constitutes personal property. ${ }^{41}$ Therefore, the entire body of law that applies to the ownership of personal property in non-insolvency situations will apply to determine the ownership of natural gas in an insolvency. For example, legal and equitable title to natural gas can be severed by way of express trusts, resulting trusts, or constructive trusts. Determining who is the legal and equitable owner of natural gas that is in the possession or control of a debtor company at the commencement of its insolvency and what rights other parties have therein requires an examination of the factual circumstances, the contractual arrangements in place, and the rules of common law, equity, and statute law.

Given that extracted natural gas is personal property, the relative interests of secured creditors in natural gas that is in the possession or control of an insolvent person may be impacted by the applicable provincial personal property security legislation. The legislation governs the creation, perfection, and priority of "security interests" in all personal property, including goods. ${ }^{42}$ A security interest is an interest granted by A to B in personal property in which $A$ has an interest, to secure $A$ 's performance of an obligation (usually, but not invariably, the repayment of debt) owed to $B$.

It is possible, and indeed commonplace, for more than one secured creditor to hold a security interest in the same personal property at the same time. When this is the casc, the relative priorities of the competing security interests must be determined. The PPSA concept of "perfection" determines priority. Security interests are most commonly perfected by way of registration in the provincial Personal Property Registries. ${ }^{43}$ The secured creditor who first perfected its security interest is entitled to receive all the proceeds of that personal property,

" Sec, e.g., Ro Bluc Range Resource Corp., [1999| A.J. No. 1665 (Q.13.) (QL).

t: The personal property security regimes are substantially identical in all Canadian provinces. Hereinafler. references to "the PPSA" refer to the Alberta Personal Property Security Act. R.S.A. 2000, c. P-7 [PPSA].

\$3 For further reading respecting the PPSA, readers are referred to Ronald C.C. Cuming \& Roderick J. Wood, Alberia Personal Propery. Securing Act Hawdbook, 4th ed. (Toronto: Carswell, 1998). 
to the exclusion of lower-ranking creditors, until it is paid in full. Then, if there remains a surplus after payment in full of the priority creditor, the surplus will be paid to the holder of the second-ranking security interest to the exclusion of all subordinate secured creditors, and so on.

\section{B. OpERator BankRUitcy SCEnARIOS}

By definition, insolvency involves a situation in which a debtor owns insulficient assets to repay all its creditors. While the likelihood of a pipeline or storage facility owner becoming insolvent may seem remote, there is always a possibility that such an event might arise, for example if an operator's parent company became insolvent. As a result, producers may experience a situation in which the operator is not in possession of enough gas to satisfy all of its obligations to producers, or a situation in which the operator's non-producer creditors have not been paid and wish to assert claims against the operator's interest in stored or shipped gas.

\section{The DIFFICULTY WITH ASSERTING OWNERSIII RIGHTS OVER STORED OR SHIPPED GAS}

Obviously, the best possible result for a producer in a gas shortage situation would be an affirmation of the producer's ownership of its stored or transported gas. and the ability to retake possession of an equal quantity of gas, free and clear of the claims of other producers or creditors. Ways in which creditors or customers outside the natural gas industry have traditionally tried to preserve their ability to retake their chattels in the event of their counterparty's insolvency are through the following types of contractual clauses:

- $\quad$ stipulating that the party in possession of the chattels will keep the chattels segregated, unmingled with other chattels, and in an identifiable form;

- reserving legal and equitable title in the property to the owner; and/or

- requiring the party having physical possession of their property to declare a trust over such property, by which the possessor holds the property for the benefit of the owner.

\section{SEGRLGintion}

Obviously, in a gas storage or transportation scenario, the operator will never be able to segregate the producer's gas molecules. They will be commingled with the gas molecules of all other producers, customers. and possibly with those of the operator as well. Segregation clauses will likely be of no practical assistance.

\section{RESERVATION OF TITLI:}

As referred to above, while Canadian courts have not addressed the issue of whether title to commingled fungible goods ean be retained by agreement, it seems that purporting expressly to reserve title to stored or shipped gas is likely a necessary precondition (or at 
least a prudent precaution) to ensuring that a producer becomes, or remains, a co-owner of the commingled quantity of gas. It is difficult to see how a producer could become a coowner (under the common law or the $W R A^{44}$ ) if it transferred all ownership rights to its own gas upon delivery. Therefore, if a producer expressly transfers title to its gas to the operator, it will have a very difficult time later trying to obtain any proprietary remedy in the event of the operator's insolvency. As a result, reservation of title would seem to be prudent in all cases, from the producer's perspective.

\section{TRUSTS}

Could a court find that a transportation or storage arrangement gives rise to a trust situation? There is a great deal of case law affirming this approach to the commingling of trust funds, (i.e., money).$^{45}$ However, as will be demonstrated below, serious difficulties arise when one tries to access any practically useful trust remedies in the situation where the commingled property is fungible, like natural gas.

\section{a. Express Trusts}

The simple declaration of a trust by an operator for the benefit of a producer (i.e., an "express trust") will probably not be effective at protecting the producer's gas. Even in simple insolvency situations where the property sought to be recovered is not commingled fungible property, it is a precondition of successfully establishing an express trust that the creditor be able to identify positively the exact property (or the traceable proceeds thereof) over which the trust was declared. ${ }^{\text {th }}$ This requirement is strictly construed, since the recognition of a trust in the insolvency setting is a very powerful remedy. Unless the court is satisfied, to a high level of probability, that the asset being "removed" from the debtor's estate and returned to the trust beneficiary, is the very same property equitably owned by the beneficiary and not another asset belonging to the debtor, a trust will not be recognized.

The difficulty of satisfying this precondition in the situation of commingled natural gas is obvious. No producer can ever identify the specific gas molecules that it delivered to the operator.

One can envision an argument, however, where an aggregate quantity of gas remains in the possession of the operator, which is greater than the volume delivered by the trust claimant, wherein the trust claimant argues that it can prove that its "trust volume" is contained therein. Perhaps such a claimant would have an even stronger argument where it was the only customer that had negotiated a declaration of trust from the operator. This hypothetical situation engages issues of tracing, which will be discussed below. In effect, such an argument would seek to have the law treat a commingled volume of natural gas in a manner similar to a mixed fund of money (where beneficiaries, depending on the facts, can sometimes successfully rely on such arguments to assert trust claims against "mixed" funds).

\$t Supra note 12.

4 Bank of Nowa Scotia v: Canada (Socicte General) (1988), 87 A.R. 133 (C.A.) [Bank of Nova Scotia].

th Re Inrig Shoe Co., [1924] 4 D.L.R. 625 (Ont. S.C.). See also Re Thompson (1930), 11 C.B.R. 263 (Ont.

S.C.). 
No Canadian case has analyzed commingled natural gas in such a fashion, and we propose below that such treatment would be unlikely.

\section{b. Constructive Trusts}

Even if an express trust will be unavailable because the relevant agreement contains no trust language, there are other potential routes to establishing a trust, the most common of which is the assertion of a constructive trust. A plaintiff seeking to establish a constructive trust need not prove that the debtor agreed to declare a trust. The strength and flexibility of the constructive trust arises from the fact that it can be awarded by the courts as a remedy.

In Canada, there are generally two methods by which a party can claim that it is the beneficiary of a constructive trust: where a defendant obtains property by a wrongful act such as the breach of an equitable duty ("wrongful conduct"); or where a defendant would be unjustly enriched to the plaintiff s detriment by being permitted to keep property for himself ("unjust enrichment"). 17

\section{"Wrongful Conduct" Constructive Trusts}

In Soulos v. Korkontzilas, McLachlin J. (as she then was) set out a number of indicia or conditions that she considered helpful in finding the existence of a constructive trust:

(1) The defendant must have been under an equitable obligation, that is, an obligation of the type that courts of equity have enforced, in relation to activities giving rise to the assets in his hands;

(2) The assets in the hands of the defendant must be shown to have resulted from deemed or actual agency activities of the defendant in breach of his equitable obligation to the plaintiff:

(3) The plaintiff must show a legitimate reason for seeking a proprietary remedy, either personal or related to the need to ensure that others like the defendant remain faithlul to their duties and;

(4) There must be no factors which would render imposition of a constructive trust unjust in all the circumstances of the case; $e$.g. the interests of intervening creditors must be protected. ${ }^{48}$

It is possible that, in an extreme case involving a storage or pipeline operator, a producer may be able to establish a "wrongful conduct" constructive trust. Dealing with the first factor, it is possible that storage or pipeline operators are fiduciaries, just as joint venture operators have been held to be. ${ }^{49}$ Second, if the operator breached its duties to a producer (presumably by dealing with the producer's gas in such a way that it was misappropriated or otherwise became unrecoverable), elements two and three might be satisfied. 
The most challenging part of a producer's claim for a "wrongful conduct" constructive trust would likely be to convince a court that it would not be "unjust" to award a proprietary remedy to the producer. By definition, all the other commingled producers will be in the same situation whenever there is insufficient gas to recover the total aggregate volume they collectively delivered. In such a scenario, any award of full recovery to a single purchaser will entail a lower recovery for one or more of the other producers. Those producers can be expected to oppose the trust claimant's argument that the imposition of trust would not be "unjust." From their perspectives, it would be extremely unjust. This "collective dilemma" will be discussed further below.

\section{(ii) "Unjust Enrichment" Constructive Trusts}

Unjust enrichment is the second route to a constructive trust. In Becker v. Pettkus, ${ }^{50}$ the Supreme Court of Canada enunciated the two-step approach for imposing a constructive trust based on unjust enrichment. First, a claim for unjust enrichment must be established and second, imposition of the constructive trust must be determined to be the appropriate relief in the circumstances. In Pettkus, Dickson J. held that entitlement to a remedy for unjust enrichment would be based on: "an enrichment, a corresponding deprivation and absence of any juristic reason for the enrichment."

Again, one can foresee circumstances in which an operator (or its customer, or another producer) may be enriched by the receipt of a producer's gas, with the producer being correspondingly deprived. The inquiry into whether there is a "juristic reason" justifying the enrichment and deprivation is really just another way of asking whether the enrichment ought to be remedied because it is "unjust." Significantly, the answer to this question may depend not only on the relative equities of the producer and the operator, but the interests of third parties may be relevant as well.

For example, Canadian courts have declined to award remedies based on unjust enrichment because of the intervening interests of third-party secured creditors. The case of McDiarmid Lumber Ltd. $v$. Canadian Imperial Bank of Commerce ${ }^{52}$ is an extreme example, in which the debtor was mistakenly paid funds to which it had no entitlement. The debtor's bank applied the funds to reduce the debtor's outstanding debt, and the bank's legal right to take funds in the debtor's possession to reduce its outstanding balance was found to be a sufficient juristic reason allowing the enrichment of the bank and preventing the mistaken payor from recovering. As well, even where a producer successfully argues that there has been unjust enrichment and it is otherwise entitled to restitution, it must still (as in all trust scenarios) be able to point to the identifiable property that is the subject of the trust, or the traceable proceeds thereof, or eise it cannot receive the benelit of a constructive trust remedy. ${ }^{53}$ Even where the hurdle of identifying or tracing the trust property is overcome, the courts still retain discretion as to whether the awarding of a proprietary remedy is appropriate. ${ }^{54}$ Commingling will make this practically impossible. 


\section{c. Can the Rules of Tracing Assist in Asserting a Trusı Claim?}

One way in which a producer could overcome the fact that it cannot positively identify the very molecules of gas it delivered for the purpose of identifying trust property would be to try to characterize the commingled mass as a "fund" of gas in order to allow application of the tracing rules that apply to money. The rules of tracing have developed at common law and in equity over hundreds of years of jurisprudence. A complete discussion of the rules is beyond the scope of this article."s

It is possible that if some, but not all, producers have negotiated for title retention or can make a trust argument, they may recover in full, to the detriment of those producers without such contractual protection. For example, consider the simple hypothetical situation of three producers who have each delivered 100 gigajoules (GJ) of gas to the operator's storage facility. Only two of the three have purported to retain title to their gas or required the operator to declare a trust for their benefit. The other has expressly transferred title to the operator. At the time of the operator's insolvency, there are only $250 \mathrm{GJ}$ of gas in the storage facility (the operator wrongly delivered $50 \mathrm{GJ}$ to a third party after the three producers injected their gas for storage). All three producers are "innocent," in the sense that none of them had anything to do with the operator's wrongful delivery.

The two producers with title retention/trust rights will attempt to assert that the remaining "fund" of gas contains the volumes held in trust for, or owned by, them. In such scenarios involving money, the law of tracing sometimes allows the wronged trust beneficiaries to take the benefit of factual presumptions to the detriment of the operator. Specifically, these two producers may be allowed the benefit of the presumption that the $50 \mathrm{GJ}$ removed from the mixed fund were gas molecules belonging to the operator (or the third producer), and not to them. Their argument would be facilitated by the fact that the third producer did not negotiate a title retention clause or trust rights for its benefit.

The applicability of such tracing rules to the natural gas scenario has not been tested in Canadian courts. However, one can foresee a significant difficulty with the courts applying such an analysis. First, unlike the money scenario, the law may regard all producers as owners in common of all natural gas in the mixed fund. In other words, if that is the case, each producer owns an undivided interest in each natural gas molecule in the mixed fund. It is an open question as to whether a declaration of trust would override this possible "default" of tenancy in common, but the impossibility of identifying the subject of any trust may convince a court that it should not.

Even if there is a chance that courts will not give any preference to producers who have attempted to retain title or obtain the benefit of trust declarations, it will be prudent for producers to attempt to retain title, perhaps to demand representations and warranties from operators that no other producer is being given higher trust/title retention rights, or otherwise to build into their contracts a similar "guarantec." Producers would be well served to attempt 
to ensure that they have at least as good trust/itle retention rights as the other producers with whom their gas will be commingled.

Setting aside the example where some but not all producers have retained title, and assuming that all producers have equal or equivalent "equities" vis-à-vis the operator (i.e., no producer is in any greater control of the operator, nor more responsible for the cause of the gas shortage in the storage facility), courts will probably incline towards having producers share the loss of any shortfall on a pro rata basis. ${ }^{56}$ This result probably makes sense and is perhaps the only logical result, if it is indeed the case that each producer has a pro rata common ownership interest in each gas molecule in the mixed mass.

As indicated above, it is not likely that a court would determine that a trust, even a constructive trust, existed between an operator and a producer over a producer's commingled natural gas. Given the findings in Deli ${ }^{37}$ and $C$ rawford ${ }^{58}$ the arrangement could be found to be a sale, perhaps with an implied term of resale at the delivery point. ${ }^{59}$ But given the overall objective and express provisions of most transportation and storage agreements, such a finding might be unlikely. As discussed above, ${ }^{60}$ the proper characterization of the relationship between operators and producers is likely either that of a bailment or a tenancy in common.

\section{Personal Property Security Considerations}

While it will not always be the case, we will assume for the purposes of this discussion that most operators will have entered into a general security agreement with their primary lender, usually a bank (the Bank). As a result, the Bank will have taken the common step of acquiring a security interest in all of the operator's present and after-acquired personal property and will have perfected that security interest by registration, prior to any particular producer having dealings with the operator. Thus, the Bank will have a first-ranking security interest in all the operator's personal property.

Where an insolvent operator cannot pay its non-producer creditors, including the Bank, those creditors might assert their security rights against all the gas in the possession of the operator, including the gas that had been delivered by producers. In this scenario, one of the issues that would have to be dealt with is the manner in which the rights of the operator's secured creditors would interact with the rights of producers. How will a producer's interest in the stored or transported gas measure up against the Bank's security interest? (C.A.), aff d [1988] 2 S.C.R. 172. Here, the courts affirmed the principle of pro rata sharing of loss rather than applying tracing nules, which would have greally benefited some trust beneficiaries and greatly harmed others, all of whom were equally "innocent" respecting the cause of the shortfall. 


\section{THE NEMO DIT PROTECTION}

Generally speaking, a debtor's mere possession of personal property is enough of an interest in that property for the debtor to grant security interests therein. ${ }^{61}$ However, the debtor can only grant a security interest over the very rights it has in the property (nemo dat quod non habet). Therefore, if the debtor has only a possessory interest in personal property, it can grant to its creditors no more than a security interest in that possessory interest. The result is that in traditional situations, an owner of personal property who has granted mere possession to a debtor, need not worry about any security interests granted therein by the debtor. The owner's interest will always "trump" the mere right of possession. Without more, there is no reason why this general rule would not apply in the commingled gas scenario: the operator only owns a common interest in the commingled gas (proportionate to the volumes of base gas owned by it or to the volumes with respect to which it has received a transfer of title from producers). Again, title retention would be prudent for all producers, as it may be a precondition to becoming an owner in common.

\section{A PPSA PITFALL}

There are, however, situations under the $P P S A^{62}$ in which the owner can lose ownership of its personal property. For example, s. 20(a)(i) of the PPSA presents such a risk in the context of bankruptcies and states:

A security interest

(a) in collaterul is not effective as against

(i) a truslee in bankruptcy if the sccurity interest is unperfected al the dale ol' bankrupley.

Therefore, if a producer's interest is considered to be a "security interest" and that security interest is not perfected as at the date of the operator's bankruptcy, the producer can actually lose its asset. This is likely a relatively rare occurrence, because the PPSA generally calls for the characterization of transactions according to their substance. In other words, the law will consider an arrangement between two parties to be a security agreement only if, in substance, the purpose of the agreement is to secure the performance of an obligation owed by one party (the grantor of the interest) to the other (the grantec). However, one could envision a producer wanting an operator to grant a security interest in the delivered gas to secure the performance by the operator of its obligation to redeliver the gas. The potential pitfalls and benefits of doing so are discussed below.

Additionally, the PPSA also "deems" some arrangements to be security agreements even when they would not otherwise satisfy the "in substance" test. The two most notable such arrangements are leases of personal property for a term greater than one year and commercial consignments of personal property. 
A lease of personal property is a transaction whereby the owner grants exclusive possession of the personal property to the other party for an agreed period of time in consideration for the payment of rent. ${ }^{63}$

"Commercial consignment" is defined in s. 1(1)(h) of the PPSA as follows:

(h) "commercial consignment" muans a consignment under which goods are delivered lor salc, lease or other disposition to a consignee who, in the ordinary course of the consignee's business, deals in goods of that description. by a consignor who,

(i) in the ordinary course of the consignor's business, deals in goods of that description, and

(ii) reserves an interest in the goods after they have been delivered,

but does not include an agreement under which goods are delivered to an auctioneer for sale or to a consignce for sale, lease or other disposition if it is generally known to the creditors of the consignee that the consignee is in the business of selling or leasing goods of others.

In lease or commercial consignment situations, it is actually possible for the owner to lose its property to a trustee in bankruptcy, even though the owner, on any "traditional" analysis, never granted more than mere possessory rights to the debtor lessee or consignec. ${ }^{6-1}$ This is because, as recognized by the Supreme Court of Canada, the personal property security regimes modify the common law principles of "title" and "ownership." As endorsed by lacobucci J. for the Court:

Provincial legislatures, faced wilh a policy choice involving the conpeting interests of the true owner and those of third parties dealing with the ostensible owner, have decided that the truc owner must forleit title. when liced with a competing interest. if she failed to register her interest as required. The court also noted that true leases were not regulated by the personal propeny regimes until recently. Thus, "as a general rule the common law did not allow the lessor's tille to leased goods to be defeated through some dealing of the lessec. However, the Personal Property Security Act has effected lar-reaching changes to the law."

Thus, because of the increased risk of lease and consignment scenarios, it will be wise to avoid structuring natural gas storage or transportation agreements in such a way that any lease or consignment elements "creep" in.

\section{APlLICABILITY OF THIE PPSA TO STORLD GAS}

The PPSA specifically discusses extracted minerals, stating that a debtor (i.e., someone who purports to grant a security interest in personal property comprising minerals) has no interest in such minerals, and therefore no ability to grant a security interest therein, until the mincrals are "extracted." "the One issue that has not yet been dealt with in PPSA jurisprudence, however, is whether natural gas loses its character as personal property if it is re-injected back into an underground reservoir for storage. If subsequent removal from the storage 
reservoir is considered to be "extraction," this argument may have some credence. The result might be that the PPSA has no application at all to gas stored in underground reservoirs.

\section{THE PPSA COMMINGLING RULES}

Section 39 of the PPSA addresses the situation where goods are commingled with other goods into an inseparable mass. The basic rules set out in $\mathrm{s.} 39$ are:

- a perfected security interest in the goods that become commingled continues in the commingled mass;

- the perfection date of a secured creditor's security interest in the commingled goods is the same as the date it perfected its security interest in the goods prior to commingling;

- a secured creditor's priority in the mass is limited to a maximum amount of the value of its security interest in the pre-commingled goods;

- if more than one perfected security interest is continued into the commingled mass under s. 39, the secured creditors are entitled to share in the commingled mass pro rata as per the market value of the secured gas that forms part of the mass; and

- a purchase money security interest (PMSI) in the pre-commingled goods generally takes priority over other security interests in the commingled mass. ${ }^{67}$

The rules set out in s. 39 will probably not produce any surprising results in a dispute between the operator's secured creditors and producers.

First, the section only governs priority competitions between security interests that were perfected prior to commingling. It is questionable (or even doubtful) whether the operator's Bank has a perfected security interest in a producer's gas prior to commingling. The Bank does not have an attached security interest in a producer's gas until, among other things, the Bank's debtor (the operator) has "rights in" the producer's gas. If the only right acquired by the operator is the right to possess the gas, this right does not arise until the moment of delivery, at which point the gas is already commingled (i.e.. the Bank's security interest is not perfected in the producer's gas until the very moment when commingling occurs and is therefore not perfected in the pre-commingled gas). However, it will be a matter of the proper interpretation of the storage agreement to determine when the operator first obtains rights in the producer's gas. An operator may have other rights in the gas that are obtained prior to delivery/commingling.

However, where the operator owns gas in the storage facility prior to a producer delivering its own gas (either because the operator owns the base gas in the facility or because other producers have transferred title in their gas to the operator), the Bank would have a perfected security interest in the pre-existing gas that then becomes commingled with the producer's gas. Section 39 would apply and the Bank's security interest in the commingled mass would 
pre-date the date of the producer's delivery. However, the Bank's security interest will be limited to the value of the operator's gas.

Notably, s. 39 does not affect a producer's interest in the gas unless that interest is a security interest. As also noted previously, it is unlikely that a producer's interest in the stored gas is "in substance" an interest that secures the performance of an obligation owed by the operator to the producer, unless explicit granting language is used in the storage agreement. If the storage agreement is drafted in such a way that the arrangement is neither a lease nor a commercial consignment of the gas, the producer's interest will not be a deemed security interest either. Therefore, s. 39 would not impact a producer's rights to its stored gas as an owner.

The application of s. 39 in the stored gas scenario seems to be most relevant, therefore, in a priority contest as between secured creditors of two or more producers. However, its application will be of practical interest only where one or more producers is insolvent or a producer and operator are simultaneously insolvent, and their respective secured creditors are seeking to assert priority to the stored or delivered gas. It is only if the producer's interest in the delivered gas is a security interest (deemed or in substance), that the section would affect the rights of a producer vis-à-vis the Bank.

\section{Practical possibilities of Enhancing a PRODUCER'S POSITION UNDER THE PPSA}

One of the questions that producers may wish to consider is whether their risk can be minimized by crafting their contracts so that the operator grants them a security interest in their stored or transported gas. The advisability of such a course of action will be determined by at least two considerations: (1) can operators realistically hope to achieve priority for such a security interest under the PPSA; and (2) will the taking of such steps under the PPSA potentially harm their chances of recovery as the owner of the gas?

Beginning with the assumption that the Bank has a "first-in-time" registration against all of the operator's present and after-acquired personal property, the question is whether producers can somehow "jump ahead" of that registration by claiming "super-priority." The most common method of doing so in the PPSA context is by way of a PMSI. PMSIs are defined in s. 1(1)(II) of the PPSA as follows:

(II) "purchase-moncy security interest" means

(i) a security interest taken or reserved in collateral to secure payment of all or part of its purchase price.

(ii) a security interest taken in collateral by a person who gives value for the purpose of enabling the debtor to acquire rights in the collateral, to the extent that the value is applied to acquire those rights,

(iii) the interest of a lessor of gexds under a lease for a term of more than one year. or

(iv) the interest of a person who delivers goods to another person under a commercial consignment. 
but does not include a transaction of sale by and lease back to the seller, and. for the purposes of this delinition, "purchase price" and "value" include credit charges or interest payable in respect of the purchase or loan.

If properly registered (see below), the secured creditor holding a PMSI enjoys superpriority over all other security interests in the personal property collateral acquired with the credit provided by the PMSI secured creditor.

The standard PMSI scenario is where a lender provides credit that the debtor uses to acquire a new piece of property. Giving the lender a super-priority in this circumstance is justifiable on a policy basis, as it encourages lenders to advance funds where there is already a first-in-time secured creditor, thereby making credit more readily available. The existing first-in-time creditor is not prejudiced, because it advanced credit when the debtor did not own the "new" asset and, therefore, it did not rely on having recourse to the new asset.

Although not often seen, one can envision a storage or transportation agreement drafted so that the producer either: (a) takes a security interest in the gas delivered to the operator to secure payment of all or part of the purchase price of the gas; or (b) gives value for the purpose of enabling the operator to acquire rights in the gas. There are some potentially serious difficulties associated with producers trying to take advantage of this approach, however.

First, it is probably the case that either of these transactions, which satisfy the PMSI test, would require the producer to transfer title in the gas to the operator. If title is transferred to the operator, the producer's ability to argue that it is a co-owner of the commingled mass is potentially eroded. The contractually agreed transfer of title might potentially bargain away the beneficial effect of the $W R A .^{68}$

Second, the PPSA contains another potential difficulty. Natural gas, in the operator's hands, may be "inventory." Inventory is defined in the PPSA as "goods":

(i) that are held by a persion for sale or lease, or that have been leased by that person.

(ii) that are to be fumished by a person or have been fumished by that person under a contract of service.

(iii) that are raw materials or work in progress, or

(iv) that are materials used or consumed in a business."

The PPSA classifies all goods as one of "inventory," "consumer goods," or "equipment." The proper characterization of goods is generally determined by the use to which the debtor (in our scenario, the operator) puts the goods when they are acquired. "Consumer goods" are defined as goods that are "used or acquired for use primarily for personal, family or household purposes. ${ }^{.70}$ Obviously, the operator does not acquire gas for that purpose. 
"Equipment" is defined as goods that are not inventory or consumer goods." Based on these definitions, there is at least a risk that gas in an operator's hands is inventory, not equipment.

To obtain a valid super-priority PMSI, there are different procedural steps to be taken, depending on whether the collateral is inventory or equipment. If the collateral is equipment, the secured creditor need only register its security interest at the provincial Personal Property Registry within 15 days of the operator obtaining possession of the gas. As long as a producer makes the registration within 15 days after it first delivers gas to the operator, all subsequent deliveries will also be protected by the PMSI. If the gas is inventory, however, the procedural steps required to obtain a valid super-priority PMSI are more oncrous. The secured creditor must: (a) register its security interest prior to the operator obtaining possession of the producer's gas; and (b) prior to delivering any gas, send a notice to all existing secured creditors advising them that the producer will be delivering gas to the operator, in which it expects to obtain a PMSI. It is arguable that the producer would have to send such a notice before every redelivery of gas (certainly if, at the time of the new delivery, the operator was holding none of the producer's gas - probably a more likely occurrence in the storage, as opposed to the transportation, scenario).

Thereforc, attempting to obtain a super-priority PMSI is a process that is potentially fraught with serious pitfalls. Not only are the registration requirements somewhat technical and potentially administratively intensive, there is also a risk that if the parties attempt to create a security agreement "in substance," a court will find that they therefore intended that the producer would not retain any ownership or property rights in the stored or transported gas. That would be potentially throwing away a producer's "trump card."

\section{Moving ToWARdS a NEW CaTEgory OF OWNERShIP}

There are many reasons why the Western Canadian natural gas industry probably, in general, wants title to remain with producers. One reason is that in the last ten to 20 years, it has become producers, not operators, that contract with downstream consumers and other purchasers of natural gas. These purchasers understandably want to be completely certain that the party they are paying for the gas is the party that has title to it, so the upstream and midstream industry participants have tried, to various degrees, to give purchasers this certainty by arranging their upstream affairs so that tille to produced natural gas remains with the producers at all times and at all phases of the processing and transportation process.

The possibility that ownership over delivered natural gas does not, in fact, remain with the producer, possibly even where there is clear and unequivocal contractual language to that effect, is probably not the outcome most industry participants would expect or desire. Further, the result in the U.S. is the opposite: producers and operators can arrange their activities to have title to shipped/stored gas remain with producers even though the gas is commingled. The high level of interconnection between the Canadian and U.S. natural gas industries is one impetus for aligning the two legal systems with respect to the ownership issue. Other reasons include certainty and protection for the industry, as well the principle of a free market economy that commercial parties should be able to arrange their affairs as 
they see fit, with a minimal level of interference from the legal system. While there are some aspects of a free market economy where a greater overall benefit arises from prohibiting certain types of activities (e.g., monopolies, cartel activities, consumer protection), it is hard to fathom a principled reason why owners of fungible goods, such as natural gas, and parties in the business of transporting or processing such goods cannot enter into a bailment.

There is merit in looking beyond the traditional concepts of title and ownership, which were not developed in or for the world of petroleum and natural gas transportation and storage, and developing a sti generis category of ownership that would essentially be treated as a bailment of commingled goods.

Such a categorization would allow producers to retain title and, therefore, security in and to delivered pipeline or storage gas. This would avoid the possibility of producers losing the value of such gas to an operator's Bank, and permit an operator to grant producers a security interest in such gas notwithstanding the producers' inability, physically and contractually, to ever regain possession of the specific molecules of gas it had delivered to the operator.

Arguments for legal evolution have previously been made by various participants in the Canadian petroleum and natural gas industry in other contexts, and have often been successful. The seminal case of Berkheiser ${ }^{72}$ involved a sui generis characterization by the Supreme Court of Canada of the petroleum and gas lease as a profit $\grave{a}$ prendre, which has become one of the central tenets of oil and gas leases today. The relationship between oil and gas lessors and lessees was further detailed and, in certain respects, created anew by the Supreme Court of Canada in Bank of Montreal v. Dynex Petroleum LId. ${ }^{73}$ and by the Saskatchewan Court of Appeal in Tavlor v. Scurry-Rainbow Oil (Sask.) Ltd. ${ }^{74}$

These cases demonstrate the willingness of the Canadian judiciary to avoid the application of traditional categories of Icgal ownership to scenarios pertaining to the petroleum and natural gas industry where such application would lead to a result that was contrary to the evidenced intention of parties and the industry as a whole. ${ }^{75}$ Perhaps the next opportunity for the courts to contribute to the development of a suigeneris body of Canadian petroleum and natural gas law will be in deciding ownership rights to commingled pipeline or storage gas.

$\because \quad$ Supros note 33.

32002 SCC 7. [2002] I S.C.R. 146.

it 2001 SKCA 85.207 Sask. R. 266.

" For a detailed discussion on recent challenges to traditional legal categories in the context of contraclual arrangements in the petroleum and natural gas industry, see Alicia K. Quesnel, "Modemiring the Property Laws That Bind Us: Challenging Traditional Property Law Concepts Unsuited to the Realities of the Oil and Gas Industry" (2003) 41 Alta. L. Rev. 159. 